Research Paper

\title{
Production and partial characterization of serine and metallo peptidases secreted by Aspergillus fumigatus Fresenius in submerged and solid state fermentation
}

\author{
Ronivaldo Rodrigues da Silva ${ }^{1}$, Tatiana Pereira de Freitas Cabral ${ }^{2}$, André Rodrigues ${ }^{3}$, \\ Hamilton Cabral ${ }^{4}$ \\ ${ }^{1}$ Instituto de Biociências, Letras e Ciências Exatas, \\ Universidade Estadual Paulista "Júlio de Mesquita Filho", São José do Rio Preto, SP, Brazil. \\ ${ }^{2}$ Faculdade de Farmácia, Centro Universitário da Fundação Educacional de Barretos, Barretos, SP, Brazil. \\ ${ }^{3}$ Departamento de Bioquímica e Microbiologia, Universidade \\ Estadual Paulista "Júlio de Mesquita Filho", Rio Claro, SP, Brazil. \\ ${ }^{4}$ Faculdade de Ciências Farmacêuticas de Ribeirão Preto, \\ Universidade de São Paulo, Ribeirão Preto, SP, Brazil.
}

Submitted: October 24, 2011; Approved: July 2, 2012.

\begin{abstract}
Enzyme production varies in different fermentation systems. Enzyme expression in different fermentation systems yields important information for improving our understanding of enzymatic production induction. Comparative studies between solid-state fermentation (SSF) using agro-industrial waste wheat bran and submerged fermentation $(\mathrm{SmF})$ using synthetic media were carried out to determinate the best parameters for peptidase production by the fungus Aspergillus fumigatus Fresen. Variables tested include: the concentration of carbon and protein nitrogen sources, the size of the inoculum, the $\mathrm{pH}$ of the media, temperature, and the length of the fermentation process. The best peptidase production during SSF was obtained after 96 hours using wheat bran at $30{ }^{\circ} \mathrm{C}$ with an inoculum of $1 \times 10^{6}$ spores and yielded 1500 active units $(\mathrm{U} / \mathrm{mL})$. The best peptidase production using $\mathrm{SmF}$ was obtained after periods of 72 and 96 hours of fermentation in media containing $0.5 \%$ and $0.25 \%$ of casein, respectively, at a pH of 6.0 and at $30^{\circ} \mathrm{C}$ and yielded $40 \mathrm{U} / \mathrm{mL}$. We also found examples of catabolite repression of peptidase production under SmF conditions. Biochemical characterization of the peptidases produced by both fermentative processes showed optimum activity at $\mathrm{pH} 8.0$ and $50^{\circ} \mathrm{C}$, and also showed that their proteolytic activity is modulated by surfactants. The enzymatic inhibition profile using phenylmethylsulfonyl fluoride (PMSF) in SmF and SSF indicated that both fermentative processes produced a serine peptidase. Additionally, the inhibitory effect of the ethylene-diaminetetraacetic acid (EDTA) chelating agent on the peptidase produced by SmF indicated that this fermentative process also produced a metallopeptidase.
\end{abstract}

Key words: metallopeptidase, serine peptidase, fermentative parameters, Aspergillus fumigatus.

\section{Introduction}

Aspergillus fumigatus Fresen. is a saprophytic organism that produces many peptidases (Bouchara et al., 1993; Gifford et al., 2002). Proteolytic enzymes are a major group of extracellular enzymes found in all forms of life, such as plants, animals and microorganisms (Haq et al., 2006). Peptidases from bacteria and fungi have many uses: the production of pharmaceuticals, food production, cleaning agents and the removal of waste proteins such as fur and feathers (Rao et al., 1998).

Microbial peptidase secretion varies between species. Each organism or strain has specific conditions for maximum enzyme production, resulting in large differences in peptidase production between submerged fermentation (SmF) and solid-state fermentation (SSF). In this context, 
filamentous fungi have been explored as a source of peptidases because they are able to grow under a range of growth conditions and they produce a variety of enzymes (Sandhya et al., 2005).

Peptidase production by species of Aspergillus, in particular, has largely been studied because these species are known for their ability to secrete high levels of enzymes during growth in their natural environments (Sandhya et al., 2005). Aspergillus fumigatus is a filamentous fungus commonly found in the soil and is an important agent in the decomposition organic matter. It is able to grow at high temperatures and is an opportunistic pathogen (Tekaia et al., 2005).

Differences in fermentation methods (SSF and SmF) and in the compositions of culture media, especially the carbon and protein nitrogen source, greatly influence peptidase production. In addition, other factors such as temperature, $\mathrm{pH}$ and fermentation time can also affect this production. Thus, this study was conducted to investigate the most favorable parameters for A. fumigatus peptidase production in submerged and solid state fermentation and to biochemically characterize the peptidases obtained from both fermentative processes.

\section{Materials and Methods}

\section{Microorganisms, strain identification and maintenance medium}

The fungus Aspergillus fumigatus was isolated from decaying wood found in soil from São José do Rio Preto, SP-Brazil. It was maintained on potato-dextrose agar (PDA) slants at $30^{\circ} \mathrm{C}$ for 168 hours to allow for complete growth. The strain was identified by a polyphasic approach using morphological and molecular markers. Preliminary microscopic examination indicated the strain belonged to the genus Aspergillus. To identify the species, we followed the standard plate regime established by Klich (2002). Briefly, the strain was cultivated for seven days in three culture media (CYA, MEA, CY20S) under different incubation temperatures $\left(5,25,37^{\circ} \mathrm{C}\right)$. Colony morphology as well as microscopic characteristics were observed and measured $(\mathrm{n}=10$ measurements in $\mu \mathrm{m})$. All characteristics were compared to detailed descriptions of common Aspergillus species (Klich, 2002) and to descriptions of $A$. fumigati (Samson et al., 2007).

DNA sequencing was used to assist strain identification. Prior to DNA extraction, the strain was cultured in $2 \%$ malt extract broth for five days at $25^{\circ} \mathrm{C}$. Then, the mycelium was recovered on a paper filter and freeze-dried overnight. DNA extraction followed the protocol of Sampaio et al. (2001) and the internal transcribed spacer region (ITS) was amplified and sequenced using the universal primer pair ITS4 and ITS5 (White et al., 1990). Both forward and reverse sequences were generated using an ABI 3500 (Applied Biosystems) and assembled into a contig using
Bioedit v.7.0.5.3 (Hall, 1999). The contig sequence was compared with homologous sequences available at NCBI-GenBank by BLASTN (Altschul et al., 1997).

Sequences of close relatives were retrieved from GenBank and aligned in Muscle v.3.6 (Edgar, 2004). Phylogenetic analyses were carried out under the neighbor-joining algorithm using the Kimura 2-parameters as the substitution model and sites with gaps/missing data were pairwise excluded from the analyses. A neighbor-joining tree was generated using MEGA5 (Tamura et al., 2011).

\section{Solid-state fermentation process}

Peptidase production by A. fumigatus in SSF was evaluated using agro-industrial waste wheat bran (W.B.). Five grams of W.B. was placed in a $250 \mathrm{~mL}$ Erlenmeyer flask and moistened with $10 \mathrm{~mL}$ of saline solution containing $0.1 \%(\mathrm{w} / \mathrm{v})$ of the following salts: $\left(\mathrm{NH}_{4}\right)_{2} \mathrm{SO}_{4}$, $\mathrm{MgSO}_{4} \times 7 \mathrm{H}_{2} \mathrm{O}$ and $\mathrm{NH}_{4} \mathrm{NO}_{3}$. The flasks were autoclaved for $40 \mathrm{~min}$ at $121{ }^{\circ} \mathrm{C}$ and the media was then inoculated with $5 \times 10^{6}$ spores for each $5 \mathrm{~g}$ of W.B. The fermentation was carried out for 168 hours, and every 24 hours one material (flasks) was removed and then was held to solubilize the enzyme in $40 \mathrm{~mL}$ of distilled water at $4{ }^{\circ} \mathrm{C}$. The solubilization was performed in a shaker for $30 \mathrm{~min}$ at $200 \mathrm{rpm}$ at $4{ }^{\circ} \mathrm{C}$. The solubilized material was then centrifuged at $8,000 \mathrm{xg}$ for $20 \mathrm{~min}$ at $4{ }^{\circ} \mathrm{C}$. The supernatant was used to quantify proteolytic activity.

The following variables were tested in SSF: the addition of casein and egg albumin inductors (5, 10 and 20\%), the concentration of spores $\left(0.1 \times 10^{6}, 1 \times 10^{6}, 2.5 \times 10^{6}\right.$ and $\left.5 \times 10^{6}\right)$ and the fermentation temperature (30, 35, 40 and $\left.45^{\circ} \mathrm{C}\right)$.

\section{Submerged fermentation process}

The media for $\mathrm{SmF}$ was prepared in $250 \mathrm{~mL}$ Erlenmeyer flasks and consisted of $50 \mathrm{~mL}$ of liquid media (standard) containing $0.7 \%(\mathrm{w} / \mathrm{v}) \mathrm{KH}_{2} \mathrm{PO}_{4}, 0.2 \%(\mathrm{w} / \mathrm{v})$ $\mathrm{K}_{2} \mathrm{HPO}_{4}, 0.01 \%(\mathrm{w} / \mathrm{v}) \mathrm{MgSO}_{4} .7 \mathrm{H}_{2} \mathrm{O}, 0.05 \%$ (w/v) citrate $2 \mathrm{H}_{2} \mathrm{O}, 0.1 \%(\mathrm{w} / \mathrm{v})$ yeast extract, $0.01 \%(\mathrm{w} / \mathrm{v}) \mathrm{CaCl}_{2} .2 \mathrm{H}_{2} \mathrm{O}$ and $1 \%(\mathrm{w} / \mathrm{v})$ peptone (Tran and Nagano, 2002). The $\mathrm{pH}$ of the media was adjusted to 6.0 , and the flasks were autoclaved for $15 \mathrm{~min}$ at $121^{\circ} \mathrm{C}$.

The following variables were tested in SmF: the addition of sucrose, glucose and fructose $(0.1,0.5$, and $1 \%)$ as carbon sources, the use of casein inductor $(0.25,0.5$ and $1 \%)$, the concentration of spores $/ \mathrm{mL}$ of medium $\left(1 \times 10^{5}\right.$, $2.5 \times 10^{5}, 5 \times 10^{5}$ and $10 \times 10^{5}$ ), the fermentation temperature $\left(30,35,40\right.$ and $\left.45^{\circ} \mathrm{C}\right)$ and the initial $\mathrm{pH}$ of the media $(5.5,6.0,6.5,7.0,7.5,8.0$ and 8.5).

The medium was inoculated with the spore suspension and incubated in a shaker at $30^{\circ} \mathrm{C}$ and $120 \mathrm{rpm}$ (orbital rotation) for 168 hours; every 24 hours one material (in flasks) was removed. The material was filtered with Whatman paper $\mathrm{n}^{\circ} 1$, and centrifuged at $8,000 \mathrm{xg}$ for $20 \mathrm{~min}$ at $4{ }^{\circ} \mathrm{C}$. The supernatant was used to quantify proteolytic 
activity and the fungal mycelium was dried at $45{ }^{\circ} \mathrm{C}$ in hot air oven (to a constant weight) to evaluate the growth of the culture.

\section{Determination of proteolytic activity}

Proteolytic activity was determined according to the protocol described by Sarath et al. (1996), with modification. The reaction mixture was composed of $1 \mathrm{~mL}$ of $1 \%$ $(\mathrm{w} / \mathrm{v})$ casein (Sigma) in a $0.05 \mathrm{M}$ monobasic sodium phosphate buffer, $\mathrm{pH} 6.5$, to which $0.2 \mathrm{~mL}$ of the enzyme solution was added. The reaction was carried out at $37^{\circ} \mathrm{C}$ and stopped with the addition of $0.6 \mathrm{~mL}$ of $10 \%$ TCA (trichloroacetic acid) after $20 \mathrm{~min}$ for SSF samples or after $60 \mathrm{~min}$ for $\mathrm{SmF}$ samples. Reactions were then centrifuged at $10,000 \mathrm{xg}$ for $15 \mathrm{~min}$ at $25^{\circ} \mathrm{C}$, and the absorbance of the supernatant was measured at $280 \mathrm{~nm}$. An appropriate control was prepared in which TCA was added before the enzymatic solution. One activity unit (U) was defined as the amount of enzyme required to liberate $1 \mu \mathrm{mol}$ tyrosine/min under the assay conditions (Meyers and Ahearn, 1977).

According to peptidase production the crude enzyme extracts that presented the best proteolytic activities in each fermentation process were concentrated by precipitation with ethanol $\left(92.8^{\circ} \mathrm{GL}\right)$ using a ratio of 1 volume of extract to 2 volumes of ethanol. Biochemical studies were performed using $1 \%$ azocasein as a substrate, according to the protocol described by Ducros et al. (2009). The reaction mixture consisted of $0.1 \mathrm{~mL}$ of partially purified enzyme extract, $0.1 \mathrm{~mL}$ of $0.05 \mathrm{M}$ HEPES buffer, $\mathrm{pH} 8.0$, and $0.2 \mathrm{~mL}$ of $1 \%$ azocasein. The mixture was incubated at $40{ }^{\circ} \mathrm{C}$ for $10 \mathrm{~min}$ and the reaction was stopped with the addition of $0.8 \mathrm{~mL} 20 \%$ TCA. Reaction and control tubes were centrifuged at $10.000 \mathrm{xg}$ for $15 \mathrm{~min}$ at $25{ }^{\circ} \mathrm{C}$, and $0.8 \mathrm{~mL}$ of supernatant was removed and added to $0.9 \mathrm{~mL}$ of $1 \mathrm{M}$ sodium hydroxide. The tubes were shaken, and the absorbance was measured with a spectrophotometer at $440 \mathrm{~nm}$ and compared to their respective controls. One activity unit (U) was defined as the amount of enzyme required to yield an increase of $0.001 \mathrm{~A}_{440 \mathrm{~nm}}$ under the conditions of the assay, as described by Morita et al. (1998), with modifications.

The effects of $\mathrm{pH}$ on the proteolytic activity was studied using the following buffers: acetate $(\mathrm{pH} 4.5$ and 5.0), MES (pH 5.5, 6.0 and 6.5), HEPES (pH 7.0 7.5 and 8.0), BICINE (pH 8.5 and 9.0) and CAPS (pH 9.5, 10.0 and 10.5), all at $0.05 \mathrm{M}$ and using azocasein as substrate. The influence of temperature on the activity of the peptidase was examined between a range of $25^{\circ} \mathrm{C}$ to $70{ }^{\circ} \mathrm{C}$, with increments of $5{ }^{\circ} \mathrm{C}$. Thermal stability was determined by incubating the enzyme at $35^{\circ} \mathrm{C}$ to $60{ }^{\circ} \mathrm{C}$ for periods of 5,10 , $15,30,45$ and $60 \mathrm{~min}$, after which proteolytic activity was assayed at $40^{\circ} \mathrm{C}$ and $\mathrm{pH}$ 8.0. The study about effect of surfactants on proteolytic activity was carried out in different concentrations, using the following surfactants, Tween 20 ,
Triton X-100, cetyltrimethylammonium bromide (CTAB) and sodium dodecil sulfate (SDS).

The mechanism of action was determined according to the protocol described by Dunn (1989), with modification. The following inhibitors were used: iodoacetic acid (IAA), phenylmethylsulfonyl fluoride (PMSF) and ethylene-diaminetetraacetic acid (EDTA), each at a final concentration of $10 \mathrm{mM}$. The reaction contained $1 \%(\mathrm{w} / \mathrm{v})$ casein (Sigma) as a substrate and was carried out at $37^{\circ} \mathrm{C}, \mathrm{pH} 6.5$.

\section{Results and Discussion}

\section{Strain identification}

Fungal colonies grown at $25^{\circ} \mathrm{C}$ on different types of media reached a diameter of 47-48, 53-54 and 30-32 mm after growth on CYA, MEA and CY20S media, respectively. At $37^{\circ} \mathrm{C}$, colony growth reached $48-49 \mathrm{~mm}$ in diameter on CYA media; no growth was observed at $5{ }^{\circ} \mathrm{C}$. Colonies grown on CYA were dark turquoise in color, with no visible exudate or soluble pigment. Stipes were light green in color, smooth, and 5.65-9.04 $\mu \mathrm{m}$ in diameter. Pyriform vesicles grew to $16.8-36.4 \mu \mathrm{m}$ in diameter. Phialides reached 6.78-12.43 x 2.26-3.39 $\mu \mathrm{m}$, and gave rise to conidia ranging in shape from globose to ellipsoidal with smooth to finely rough walls $(2.8-3.39 \mu \mathrm{m}$ in diameter). Overall, colony morphology and microscopic characteristics matched the descriptions of Aspergillus section fumigati (Klich, 2002; Samson et al., 2007).

The complete ITS region (560 base pairs) was sequenced for the strain. BLASTN results indicated that available sequences of $A$. fumigatus in the public database were $99 \%$ identical to our sequence. Furthermore, phylogenetic analysis classified our strain as co-specific to other $A$. fumigatus strains (Figure 1).

\section{Peptidase production profile by submerged and solid-state fermentation}

The fermentative process is greatly influenced by the nature of the substrate. Several additional parameters affect the production of enzymes in the fermentation process, including time, moisture content, temperature and nutrition supplements such as carbon and nitrogen (Sumantha et al., 2005).

\section{Effect of inductor in the peptidase production}

We investigated the influence of an inductor, casein, on peptidase production in submerged fermentation. The use of $0.5 \%$ casein induced maximum peptidase production in 72 hours, and the addition of $0.25 \%$ casein induces maximum peptidase production after 96 hours. The amount of peptidase produced under both conditions was $40 \mathrm{U} / \mathrm{mL}$ (Figure 2a).

In SSF, the greatest peptidase yield was achieved using W.B. $(100 \%)$ as substrate for a fermentation period of 
96 hours, with $1300 \mathrm{U} / \mathrm{mL}$ (Figure 2b). Notably, the peak peptidase production in SSF was obtained using W.B. and was approximately two-fold higher than the peak production reached with $5 \%$ egg albumin or casein protein supple- ments. Other recent studies also found the highest production of peptidases using W.B. as substrate for SSF (Macchione et al., 2008, Sandhya et al., 2005). Wheat bran is an excellent substrate for SSF because of its composition,

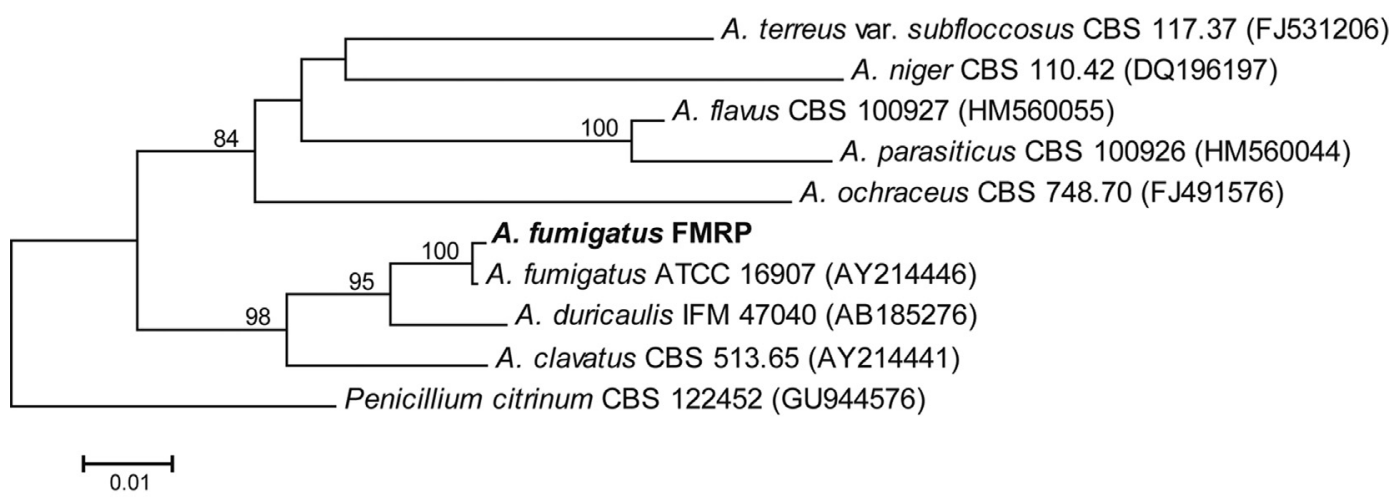

Figure 1 - Neighbor-joining tree inferred from a 531-base pair fragment of the internal transcribed spacer region (ITS) of selected Aspergillus spp. The tree was inferred under the Kimura 2-parameters substitution model. Numbers on branches are bootstrap support values obtained from 1,000 pseudoreplicates. The strain FMRP evaluated in this study is denoted in bold. Sequences are followed by the culture collection voucher number and the GenBank accession numbers in parentheses. An ITS sequence of Penicillium citrinum was used as an outgroup.
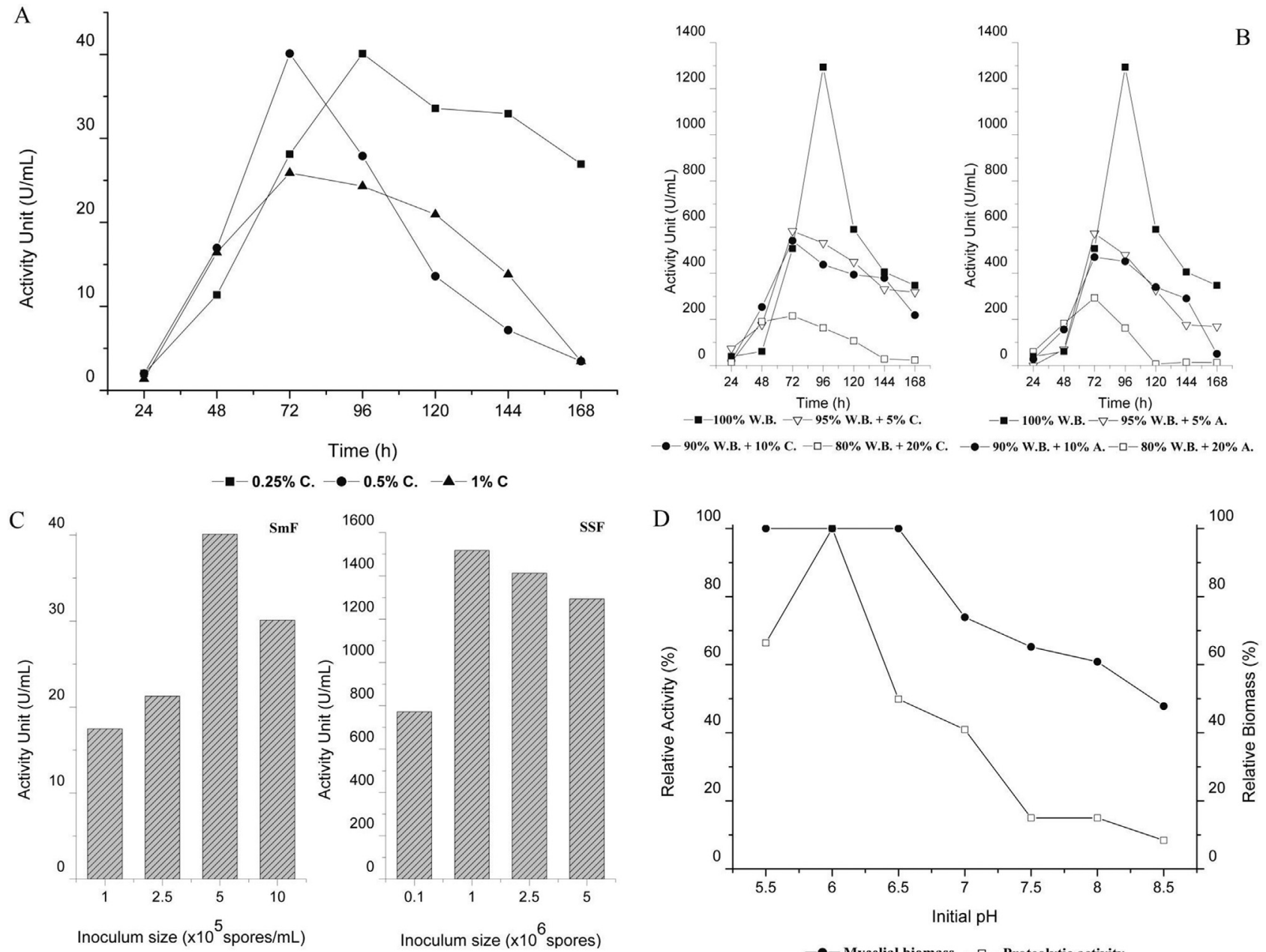

Figure 2 - Peptidase production by A. fumigatus in SmF and SSF. Effect of inductors (Casein (C) and egg albumin (A)) in SmF (a) and SSF (b). Effect of the inoculum size (c) and effect of the initial $\mathrm{pH}$ of the media in $\mathrm{SmF}(\mathrm{d})$. 
protein content, texture and porosity facilitate the access and the dispersion of fungi (Pandey, 2003). The high protein content of W.B. (18\% protein) may have contributed strongly to the amount of peptidase produced (Madruga and Camara, 2000).

However, in SSF media with $20 \%$ protein supplementation, the maximum peptidase production was approximately $200 \mathrm{U} / \mathrm{mL}$ for casein and $300 \mathrm{U} / \mathrm{mL}$ for egg albumin. Interestingly, this trend was observed in both fermentation methods, indicating that the increased concentration of inductor promoted a reduction in proteolytic activity. In comparison to the best peptidase production conditions, in $\mathrm{SmF}$ in the presence of $1 \%$ casein, the decline of 1.5 times in the proteolytic activity proves that the rise in the concentration of protein inductor also acts as a repressor in the production of peptidases. A similar result has also been shown with Actinomycete in SSF (Mehta et al., 2006).

The composition of the growth media is a factor in determining the amount and the type of peptidase produced. In this work there was a highest peptidase production in SSF, we found that SSF yielded approximately 30 times more peptidase than SmF, probably because the high protein content of W.B and due to the media is closer of the natural microbial growth conditions (Pandey, 2003). Gifford et al. (2002) observed that proportion of serine peptidases and metallopeptidases produced depends on the proteic substrate utilized by the fungus $A$. fumigatus.

\section{Effect of the inoculum size and temperature in the peptidase production}

The inoculum size and growth temperature are important biological factors that determine the metabolic production and biomass of the fermentation process. Thus, the density of spores used to inoculate fermentation cultures is a fundamental parameter in fungal growth (Sandhya et al., 2005). Among the studied concentrations of spores, we found that the maximum peptidase production in $\mathrm{SmF}$ and SSF was with $5 \times 10^{5}$ spores $/ \mathrm{mL}$ and $1 \times 10^{6}$ spores, respectively (Figure 2c).

These results indicate that the concentration of nutrients was sufficient for fungal growth and peptidase production, allowing a better hydrolysis of proteins and an increase in amino acids available as nitrogen sources. However, it was also observed that concentrations greater than and less than the ideal spore concentration resulted in decreased peptidase production. A similar result was shown with Aspergillus oryzae in SSF (Sandhya et al., 2005).

The effect of the temperature in SmF and SSF revealed that the best peptidase production occurred at $30^{\circ} \mathrm{C}$ and that increasing the temperature resulted in a decrease in peptidase production in both fermentative processes (Table 1). The correlation between increased temperature and decreased proteolytic activity has also been shown in Penicillium chrysogenum (Haq et al., 2006).
Table 1 - Effects of different temperatures in SmF and SSF on peptidase production.

\begin{tabular}{lcc}
\hline Temperature $\left({ }^{\circ} \mathrm{C}\right)$ & Peak production SmF & Peak production \\
\hline SSF & & \\
30 & 40 & 1300 \\
35 & 39 & 477 \\
40 & 16.3 & 425 \\
45 & 6.47 & 84 \\
\hline
\end{tabular}

Peak peptidase production $(\mathrm{U} / \mathrm{mL})$ at different temperatures $(30,35,40$ and $45^{\circ} \mathrm{C}$ ) in $\mathrm{SmF}$ and SSF. SmF process were performed in medium with $0.5 \%$ casein, $5 \times 10^{5}$ spores $/ \mathrm{mL}$, and $\mathrm{pH} 6.0$. SSF process used wheat bran as substrate and an inoculum of $5 \times 10^{6}$ spores.

\section{Effect of carbon sources on peptidase production in submerged fermentation}

The effect of the addition of carbon sources (glucose, fructose and sucrose) at different concentrations (0.1, 0.5 and $1 \%$ ) to SmF process was also studied. The results showed that peptidase production was repressed in all samples that contained glucose, fructose or sucrose. The highest level of peptidase production $(28 \mathrm{U} / \mathrm{mL})$ was obtained in the presence of $0.5 \%$ glucose after 168 hours of fermentation, and the lowest level of production $(4.5 \mathrm{U} / \mathrm{mL})$ occurred after 168 hours of fermentation in the presence of $1 \%$ sucrose. A comparison between these results and the results of fermentation using standard medium $(0.5 \%$ casein without carbon source), which yielded an enzymatic activity of $40 \mathrm{U} / \mathrm{mL}$, shows that the addition of these sugars as a carbon source resulted in the repression of peptidase production (Table 2). The repressive effect of the sugars is due to the presence of a carbon source that is easy to absorb; the fungus A. fumigatus produces peptidases slowly, after 168 hours of fermentation, and when the carbon sources in the media have been depleted. Catabolite repression by the addition of carbon sources has also been reported by others researchers (Abidi et al., 2008; Haddar et al., 2011).

\section{Effect of the initial $\mathrm{pH}$ of the media on peptidase production in submerged fermentation}

The $\mathrm{pH}$ of the media greatly influences fungal growth, affecting mechanisms such as enzyme secretion and cellular

Table 2 - Effect of different concentrations of carbon sources on peptidases production.

\begin{tabular}{lcccc}
\hline Carbon sources & $0 \%$ & $0.1 \%$ & $0.5 \%$ & $1 \%$ \\
\hline Standard medium & 40 & - & - & - \\
Glucose & - & 18 & 28.1 & 13.6 \\
Fructose & - & 26.5 & 24.8 & 6.7 \\
Sucrose & - & 19.7 & 15.7 & 4.5 \\
\hline
\end{tabular}

Peak peptidase production $(\mathrm{U} / \mathrm{mL})$ after 168 hours of fermentation with different percentages $(0.1 \% ; 0.5 \%$ and $1 \%)$ of glucose, fructose and sucrose. The fermentations were conducted in medium with $0.5 \%$ casein, $5 \mathrm{x}$ $10^{5}$ spores $/ \mathrm{mL}$ and carried out at $30^{\circ} \mathrm{C}$. 
transport (Moon and Parulekar, 1991; Sandhya et al., 2005). In this study, peak peptidase production was obtained with growth in media at a $\mathrm{pH}$ of 6.0 (Figure $2 \mathrm{~d}$ ). At this $\mathrm{pH}$, the fungus reached the highest levels growth and peptidase production, showing an association between fungal growth and production of proteolytic enzymes. Increasing the initial $\mathrm{pH}$ of the medium resulted in a significant decrease in enzymatic production. Similar results have been demonstrated for the fungi Penicillium chrysogenum (Haq et al., 2006) and Aspergillus oryzae (Sandhya et al., 2005).

\section{Partial characterization of the produced peptidases}

\section{Effect of the $\mathrm{pH}$ in the activity and stability on the peptidase}

The effect of $\mathrm{pH}$ on the activity and stability of the peptidases obtained from SmF and SSF was determined us- ing $1 \%$ azocasein as a substrate. Peptidases obtained from both fermentation processes demonstrated a wide range of activity with a strong alkaline tendency. They showed maximum activity at a $\mathrm{pH}$ of 8.0 and were stable at all $\mathrm{pH}$ levels tested (Figure 3a). The ability of others species of Aspergillus to secrete alkaline peptidases was described by Tunga et al. (2003) and Hajji et al. (2008); optimum activity was obtained at $\mathrm{pH} 8.0$ and 8.5 , respectively. The production of alkaline peptidases by A. fumigatus has also been noted in other studies (Larcher et al., 1992; Wang et al., 2005).

\section{Effect of the temperature in the activity and stability of the peptidase}

The effect of temperature on the activity of the peptidases was studied at $\mathrm{pH} 8.0$ using 1\% azocasein as a sub-
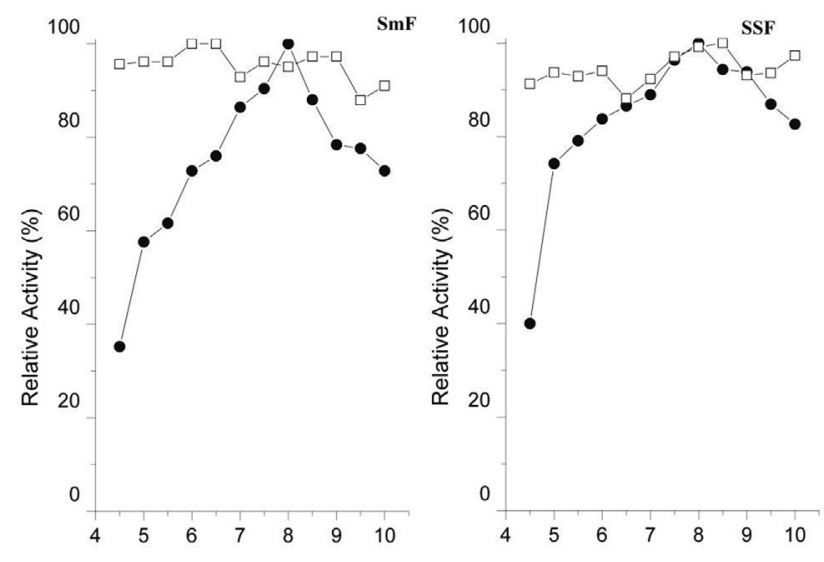

$\mathrm{pH}$

A

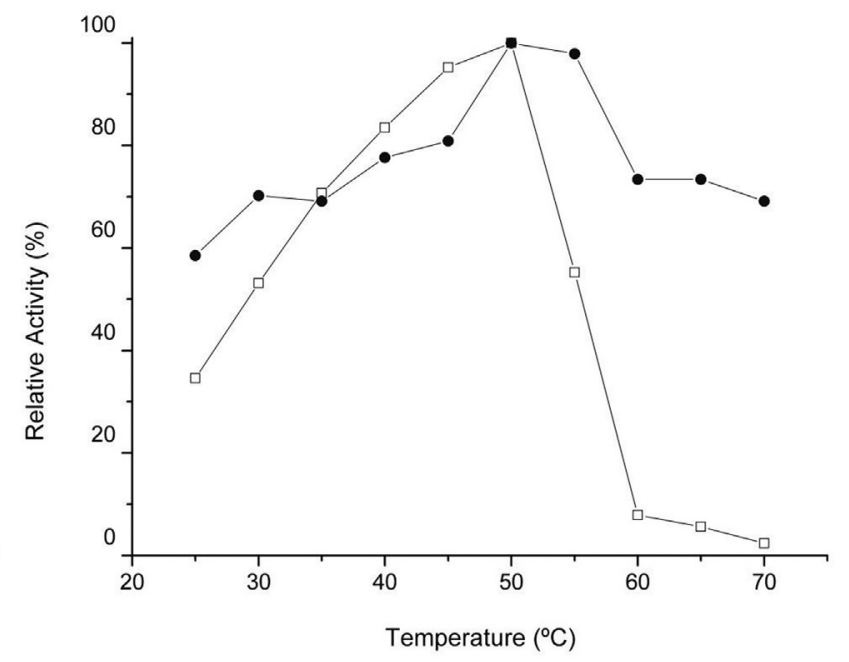

B

Peptidases from SmF (- - ) and SSF (- - $)$

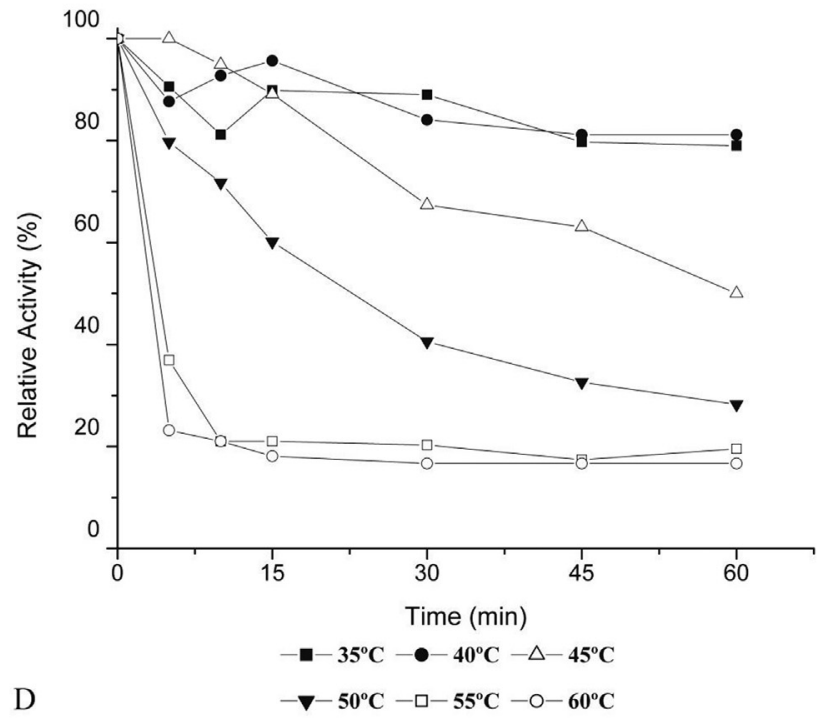

$\mathrm{C}$

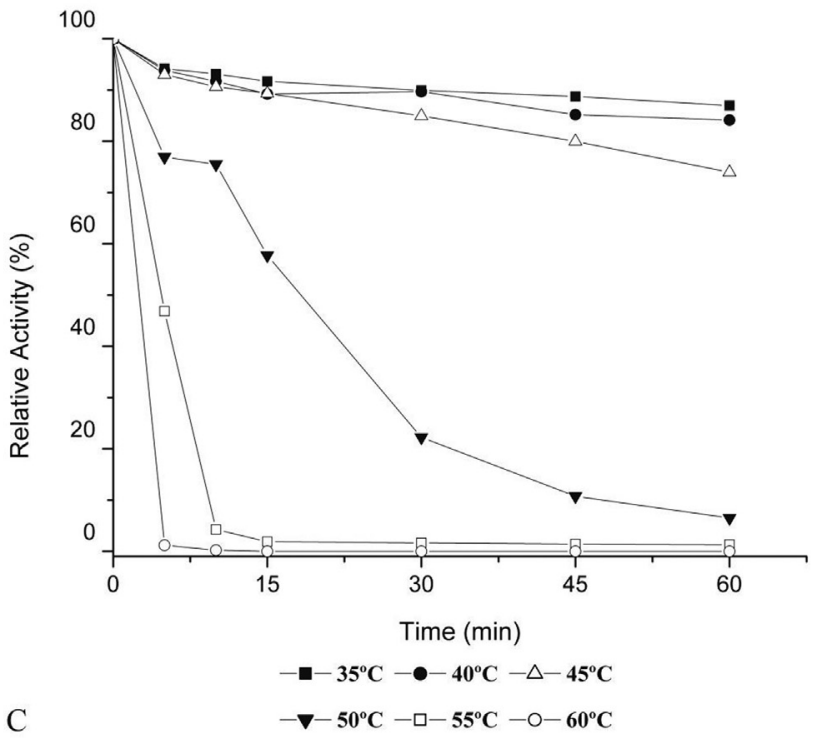

Figure 3 - Partial characterization of the peptidases produced in SmF and SSF. Effect of the pH in the activity and stability (a). Effect of the temperature in the activity (b) and stability of the peptidase produced in SSF (c) and SmF (d). 
strate. The activity was examined for temperatures between 25 to $70{ }^{\circ} \mathrm{C}$, with the optimum activity occurring at $50^{\circ} \mathrm{C}$ for both peptidases. The peptidase produced by SmF maintained $70 \%$ of relative activity at $70{ }^{\circ} \mathrm{C}$, in contrast to the peptidase obtained in SSF, which showed an abrupt decrease in activity at temperatures above $50{ }^{\circ} \mathrm{C}$ (Figure $3 \mathrm{~b}$ ). The results of the thermal stability assay showed that the peptidase obtained by SSF had a residual activity of $80 \%$ after $60 \mathrm{~min}$ of exposure to a temperature of $45^{\circ} \mathrm{C}$, but it maintained only $20 \%$ of the initial proteolytic activity after 30 min of exposure to a temperature of $50{ }^{\circ} \mathrm{C}$ (Figure 3c). The peptidase obtained by $\mathrm{SmF}$ showed a higher stability than the peptidase from SSF; after $30 \mathrm{~min}$ of exposure to a temperature of $50{ }^{\circ} \mathrm{C}$, the peptidase maintained $40 \%$ of its initial activity (Figure $3 \mathrm{~d}$ ).

Point out that each method used for enzyme production presents self characteristics, leading to a different production between the systems of fermentation, justifying the induction of peptidases with unique biochemical properties. In addition, when referring it to thermal stability of enzyme extracts; the enzyme relation with other compounds (proteins and carbohydrates) is a factor of great influence on peptidase stability.

\section{Effect of surfactants in the activity of the peptidase}

The influence of different concentrations of several surfactants on enzymatic activity was assessed. The peptidases were highly stable in the presence of non-ionic surfactants (Tween 20 and Triton X-100). However, the proteolytic activity of both fermentative extracts (SSF and $\mathrm{SmF}$ ) was reduced in the presence of cationic (CTAB) and anionic (SDS) surfactants. In comparison with the control reaction, the addition of $0.8 \% \mathrm{CTAB}$ reduced proteolytic activity by approximately $60 \%$ for SSF and $25 \%$ for SmF, and the addition of $0.8 \%$ SDS reduced proteolytic activity by approximately $70 \%$ for SSF and $65 \%$ for SmF (Figure $4 a$ and $b$ ). These results are likely due to the denaturing activity of surfactants, which releases non-covalent bonds, thus decreasing proteolytic activity (Berg et al., 2002). Decreased proteolytic activity in the presence of SDS has also been shown in peptidases from Aspergillus clavatus ES1 (Hajji et al., 2008) and Penicillium sp. (Agrawal et al., 2004).

\section{Effect of inhibitors on the activity of the peptidase}

The catalytic mechanism of action of peptidases can be identified by their responses to different enzyme inhibitors. In the study about effect of inhibitors, in presence of IAA $(10 \mathrm{mM})$ and EDTA $(10 \mathrm{mM})$, the peptidase obtained from A. fumigatus SSF did not present inhibition of the proteolytic activity, whose residual activities were $98 \%$ and 93\%, respectively. However, in presence of PMSF $(10 \mathrm{mM})$, the peptidase was almost completely inhibited (residual activity of 5\%) indicating that it is a serine peptidase. Differently, the proteolytic activity of the peptidase
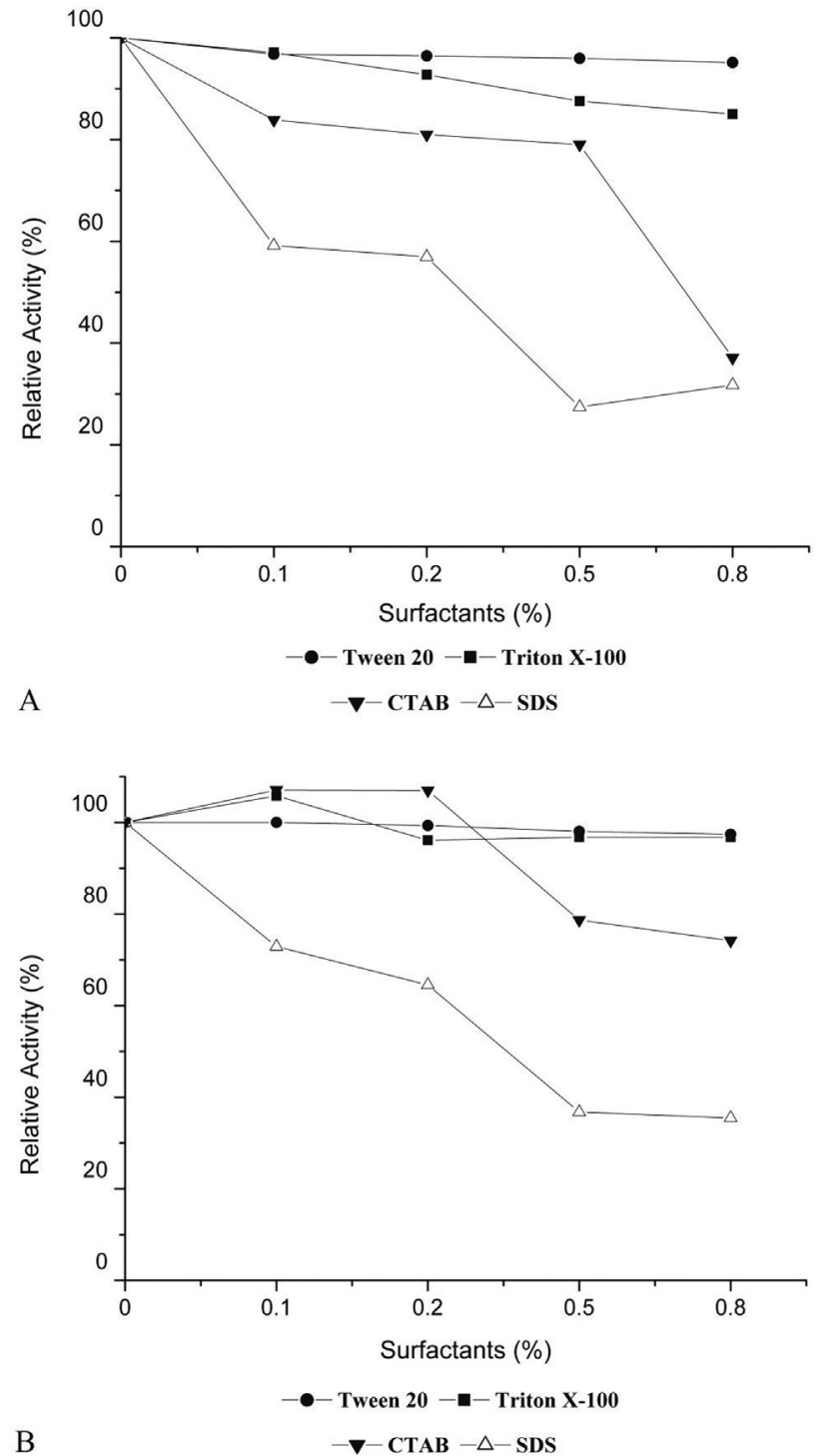

Figure 4 - Effect of surfactants on SSF peptidases (a) and SmF peptidases (b).

produced by $\mathrm{SmF}$ was approximately $50 \%$ and $45 \%$ of the original activity after incubation with PMSF $(10 \mathrm{mM})$ and EDTA $(10 \mathrm{mM})$, respectively. In addition, studies shown that increasing the concentration of PMSF $(5,10,15$ and $20 \mathrm{mM}$ ) did not further inhibit the proteolytic activity of the SmF peptidase, and the mixture between PMSF $(10 \mathrm{mM})$ and EDTA $(10 \mathrm{mM})$ promoted highest reduction of the proteolytic activity (residual activity of 5\%) indicating that more than one peptidase class was present. This inhibition profile indicates that $\mathrm{SmF}$ produces both serine peptidases and metallopeptidases. The production of serine peptidases in SSF by the fungus A. fumigatus have also described by Wang et al. (2005) and Larcher et al. (1992), and Markaryan et al. (1994) has described metallopeptidase production by $A$. fumigatus.

In conclusion, fungal growth parameters influence peptidase production by $A$. fumigatus. Interestingly, we 
found that SSF yielded approximately 30 times more peptidase than $\mathrm{SmF}$, being the wheat bran an excellent substrate for peptidase production. In this work there was production of alkaline peptidases with optimum activities at $50{ }^{\circ} \mathrm{C}$, wide range $\mathrm{pH}$ stability and more stable in presence of non-ionic surfactants. We also found differences in the types of peptidases produced by the different fermentative processes; serine peptidase and metallopeptidase were produced by SmF but SSF extract contained only serine peptidases. These results are important for future studies concerning the induction of peptidase production by the type of fermentative medium and indicate that enzyme production not only varies between fungal species but also can be influenced by the use of different fermentative processes.

\section{Acknowledgments}

The authors would like to acknowledge the financial support provided by Fundação de Amparo à Pesquisa do Estado de São Paulo, FAPESP, Conselho Nacional de Desenvolvimento Científico e Tecnológico and Instituto Nacional de Ciência e Tecnologia-Rede de Biotecnologia Farmacêutica.

\section{References}

Abidi F, Limam F, Nejib MM (2008) Production of alkaline proteases by Botrytis cinerea using economic raw materials: Assay biodetergent. Process Biochem 43:1202-1208.

Agrawal D, Patidar P, Banerjee T, Patil S (2004) Production of alkaline protease by Penicillium sp. under SSF conditions and its application to soy protein hydrolysis. Process Biochem 39:977-981.

Altschul SF, Madden TL, Schaffer AA, Zhang J, Zhang Z, Miller W, Lipman DJ (1997) Gapped BLAST and PSI-BLAST: a new generation of protein database search programs. Nucl Acids Res 1:3389-3402.

Berg JM, Tymoczko JL, Stryer L (2002) Biochemistry. 5th ed. W. H. Freeman, New York.

Bouchara JP, Larcher G, Joubaud F, Penn P, Tronchin G, Chabasse D (1993) Extracellular fibrinogenolytic enzyme of Aspergillus fumigatus: substrate-dependent variations in the proteinase synthesis and characterization of the enzyme. FEMS. Immunol Med Microbiol 7:81-91.

Ducros E, Ferrari M, Pellegrino M, Raspanti C, Bogni C (2009) Effect of aeration and agitation on the protease production by Staphylococcus aureus mutant RC128 in a stirred tank bioreactor. Bioprocess Biosyst Eng 32:143-148.

Dunn BM (1989) Determination of protease mechanism. In: Beynon RJ, Bond JS (eds) Proteolytic Enzymes: A Practical Approach. IRL Press, NY, pp 57-81.

Edgar RC (2004) MUSCLE: multiple sequence alignment with high accuracy and high throughput. Nucl Acids Res 32:1792-1797.

Gifford AH, Klippenstein JR, Moore MM (2002) Serum stimulates Growth of and proteinase secretions by Aspergillus fumigatus. Infect Immun 70:19-26.
Haddar A, Hmidet N, Ghorbel-Bellaaj O, Fakhfakh-Zouari N, Sellami-Kamoun A, Nasri M (2011) Alkaline proteases produced by bacillus licheniformis RP1 grown on shrimp wastes: Application in chitin extraction, chicken featherdegradation and as a dehairing agent. Biotechnol Bioproc Eng 16:669-678

Hajji M, Rebai A, Gharsallah N, Nasri M (2008) Optimization of alkaline protease production by Aspergillus clavatus ES1 in Mirabilis jalapa tuber powder using statistical experimental design. Appl Microbiol Biotechnol 79:915-923.

Hall TA (1999) BioEdit: a user-friendly biological sequence alignment editor and analysis program for Windows 95/98/NT. Nucl Acids Symp Ser 41:95-98.

Haq IU, Mukhtar H, Umber H (2006) Production of Protease by Penicillium chrysogenum Through Optimization of Environmental Conditions. J Agri Soc Sci 2:23-25.

Klich MA (2002) Identification of common Aspergillus species. Centraalbureau voor Schimmelcultures, Utrecht.

Larcher G, Bouchara JP, Annaix V, Symoens F, Chabasse D, Tronchin G (1992) Purification and characterization of a fibrinogenolytic serine proteinase from Aspergillus fumigatus culture filtrate. FEBS Lett 308:65-69.

Macchione MM, Merheb CW, Gomes E, da Silva R (2008) Protease production by different thermophilic fungi. Appl Biochem Biotechnol 146:223-230.

Madruga MS, Camara FS (2000) The chemical composition of "Multimistura" as a food supplement. Food Chem 68:41-44.

Markaryan A, Morozova I, Yu H, Kolattukudy PE (1994) Purification and characterization of an elastinolytic metalloprotease from Aspergillus fumigatus and immunoelectron microscopic evidence of secretion this enzyme by the fungus invading the murine lung. Infect Immun 62:2149-2157.

Mehta VJ, Thumar JT, Singh SP (2006) Production of alkaline protease from an alkaliphilic actinomycete. Biores Technol 97:1650-1654.

Meyers SP, Ahearn DG (1977) Extracellular proteolysis by Candida lipolytica. Mycologia 69:646-651.

Moon SH, Parulekar SJ (1991) A parametric study of protease production in batch and fed-batch cultures of Bacillus firmus. Biotechnol Bioeng 37:467-483.

Morita Y, Hasan Q, Sakagushi T, Murakami Y, Yokoyama K, Tamiya E (1998) Properties of a cold-active protease from psychrotrophic Flavobacterium balustinum P104. Appl Microbiol Biotechnol 50:669-675.

Pandey A (2003) Solid-state fermentation. Biochem Eng J 13:8184.

Rao MB, Tanksale AM, Ghatge MS, Deshpande VV (1998) Molecular and biotechnological aspects of microbial proteases. Microbiol Mol Biol Rev 62:597-635.

Sampaio JP, Gadanho M, Santos S, Duarte FL, Pais C, Fonseca A, Fell JW (2001) Polyphasic taxonomy of the basidiomycetous yeast genus Rhodosporidium: Rhodosporidium kratochvilovae and related anamorphic species. Int J Syst Evol Microbiol 51:687-697.

Samson RA, Hong S, Peterson SW, Frisvad JC, Varga J (2007) Polyphasic taxonomy of Aspergillus section Fumigati and its teleomorph Neosartorya. Stud Mycol 59:147-203.

Sandhya C, Sumantha A, Szakacs G, Pandey A (2005) Comparative evaluation of neutral protease production by Aspergillus oryzae in submerged and solid-state fermentation. Process Biochem 40:2689-2694. 
Sarath G, de la Motte RS, Wagner FW (1996) Protease assay methods. In: Beynon RJ, Bond JS (eds) Proteolytic enzymes: A Practical Approach. IRL Press, NY, pp 25-55.

Sumantha A, Sandhya C, Szakacs G, Soccol C R, Pandey A (2005) Production and partial purification of a neutral metalloprotease by fungal mixed substrate fermentation. Food Technol Biotechnol 43:313-319.

Tamura K, Peterson D, Peterson N, Stecher G, Nei M, Kumar S (2011) MEGA5: molecular evolutionary genetics analysis using maximum likelihood, evolutionary distance, and maximum parsimony methods. Mol Biol Evol 28:2731-2739.

Tekaia F, Latgé JP (2005) Aspergillus fumigatus: saprophyte or pathogen? Curr Opin Microbiol 8:385-392.

Tran LH, Nagano H (2002) Isolation and characteristics of Bacillus subtilis $\mathrm{CN} 2$ and its colagenase production. J Food Sci 67:1184-1187.
Tunga R, Shrivastava B, Banerjee R (2003) Purification and characterization of a protease from solid state culture of Aspergillus parasiticus. Process Biochem 38:1553-1558.

Wang S-L, Chen Y-H, Wang C-L, Yen Y-H, Chern M-K (2005) Purification and characterization of a serine peptidase extracellularly produced by Aspergillus fumigatus in a shrimp and crab shell powder medium. Enzyme Microb Technol 36:660-665.

White TJ, Bruns T, Lee S, Taylor J (1990) Amplification and direct sequencing of fungal ribosomal RNA genes for phylogenetics. In: Innis MA, Gelfand DH, Sninsky JJ, White TJ (eds). PCR Protocols: A Guide to Methods and Applications. Academic Press, CA, pp 315-321.

All the content of the journal, except where otherwise noted, is licensed under a Creative Commons License CC BY-NC. 